\title{
Pengaruh Variasi Kadar Pengisi Laktosa dan Manitol terhadap Sifat Fisik Granul sebagai Produk Antara Tablet Effervescent Ekstrak Daun Senna (Cassia acutifolia)
}

\author{
Mayu Rahmayanti ${ }^{1^{*}}$ \\ ${ }^{1}$ Program Studi Farmasi, Fakultas Kedokteran dan Ilmu Kesehatan Universitas Islam Negeri Maulana Malik Ibrahim, \\ Malang, Indonesia \\ *Corresponding Author. E-mail: mayu31@farmasi.uin-malang.ac.id
}

\begin{abstract}
Senna leaf (Cassia acutifolia) is a plant that is widely known by the public to treat constipation. Senna leaf products have weaknesses in the form, taste and use irrational doses, so it needs to be formulated into pharmaceutical preparations with good quality, safety, and effectiveness. In pharmaceutical preparations, physical properties affect the quality of the preparations produced, both in intermediate and finished products. This study aims to determine the effect of variations in the levels of lactose and mannitol as filler on the physical properties of the effervescent granules of senna leaf extract. Effervescent granules were made using the melting method with a ratio of lactose and mannitol 25\%:75\%,50\%:50\%, and $75 \%: 25 \%$, while the extraction method for senna leaves used the infundation method with distilled water as a solvent. The effervescent granules obtained were tested for flow time, angle of repose, powder tapping and moisture content. The data obtained were analyzed by theoretical approach and statistical test using analysis of variance (ANOVA) with 95\% confidence level. The results showed that the use of variations in the filler levels of lactose and mannitol with groups of $25 \%: 75 \%, 50 \%: 50 \%$, and $75 \%: 25 \%$, could affect the moisture content and angle of repose of the granules but had no effect on the compressibility and flow time of the granules. Mannitol with greater concentration increased the moisture content and angle of repose effervescent granules of senna leaf extract.
\end{abstract}

Keywords : Cassia acutifolia, sennoside, laxative, effervescent granules, mannitol, lactose

\section{ABSTRAK}

Daun senna (Cassia acutifolia) merupakan tanaman yang sudah banyak dikenal oleh masyarakat untuk mengatasi konstipasi. Produk daun senna memiliki kelemahan berupa aroma dan rasa yang tidak enak, serta penggunaan dosis yang tidak tepat sehingga perlu untuk diformulasikan ke dalam sediaan farmasi yang memenuhi syarat kualitas, keamanan, dan efektifitas. Pada pembuatan sediaan farmasi, sifat fisik merupakan salah satu faktor yang mempengaruhi kualitas sediaan yang dihasilkan, baik pada produk antara maupun produk jadi. Penelitian ini bertujuan untuk mengetahui pengaruh variasi kadar pengisi laktosa dan manitol terhadap sifat fisik granul effervescent ekstrak daun senna. Granul effervescent dibuat menggunakan metode peleburan dengan perbandingan laktosa dan manitol 25\%: 75\%, 50\%: 50\%, dan 75\%: 25\% sedangkan metode ekstraksi daun senna menggunakan metode infundasi dengan pelarut akuades. Granul effervescent yang diperoleh diuji waktu alir, sudut diam, pengetapan dan susut pengeringan. Data yang diperoleh dianalisis dengan pendekatan teoritis dan uji statistik menggunakan analisis of varian (ANOVA) dengan taraf kepercayaan $95 \%$. Hasil penelitian menunjukkan bahwa penggunaan variasi kadar pengisi laktosa dan manitol dengan kadar 25\%: $75 \%, 50 \%$ : 50\%, dan 75\%: $25 \%$ dapat mempengaruhi kadar air dan sudut diam granul, namun tidak berpengaruh pada kompresibilitas dan waktu alir granul. Semakin besar konsentrasi manitol semakin besar kadar air dan sudut diam granul effervescent esktrak daun senna.

Kata kunci : Cassia acutifolia, sennosida, laksatif, granul effervescent, manitol, laktosa.

Submitted: November $27^{\text {th }} 2021 \mid$ Accepted: December 19th 2021| Published: December $31^{\text {st }} 2021$

\section{Pendahuluan}

Penggunaan obat dari bahan alam banyak digunakan oleh masyarakat Indonesia, karena merupakan salah satu warisan dan tradisi dari nenek moyang secara turun temurun [1]. Bahan baku obat yang berasal dari tanaman dinilai memiliki beberapa kelebihan diantaranya terkait dengan resiko munculnya efek samping yang lebih ringan dibandingkan dengan obat sintesis jika digunakan dengan tepat dan benar. Ketepatan penggunaan obat dari bahan alam meliputi kebenaran obat, ketepatan dosis, ketepatan cara, waktu penggunaan, ketepatan indikasi, dan ketepatan informasi [2].

Cassia acutifolia adalah tanaman yang banyak dijumpai di Indonesia dan telah banyak dimanfaatkan untuk mengatasi konstipasi atau sulit buang air besar. Tanaman ini lebih banyak dikenal dengan nama jati cina atau senna. Efek laksatif yang dimiliki oleh senna pun telah banyak diteliti dan juga dimanfaatkan sebagai obat pelangsing atau penurun berat badan di masyarakat luas. Pemanfaatan daun senna telah disetujui oleh World Health Organization (WHO) sebagai obat konstipasti 
atau laksatif [11]. Efek laksatif yang dihasilkan dari daun senna dikarenakan adanya kandungan senyawa metabolit sekunder yaitu glikosida antrakuinon [12]. Senna mengandung glikosida antrakuinon yaitu senosida A dan senosida B. Senosida dan metabolit aktifnya seperti rhein-anthron dapat bekerja melalui dua mekanisme aksi yaitu mempengaruhi motilitas usus besar dan mempengaruhi proses sekresi air serta elektrolit [3].

Formulasi daun senna menjadi sediaan tablet effervescent belum banyak dikembangkan, daun senna yang beredar di masyarakat banyak dijual dalam bentuk serbuk simplisia seperti teh maupun kapsul. Formulasi senna menjadi sediaan tablet effervescent merupakan salah satu cara yang dapat meningkatkan nilai dari tanaman senna itu sendiri dan menjadi alternatif produk yang memiliki efektifitas dan keamanan saat dikonsumsi oleh masyarakat. Sediaan tablet effervescent adalah sediaan yang mengandung campuran komponen asam dan basa yang akan menghasilkan gas saat dilarutkan di dalam air [4]. Sediaan ini dapat memberikan rasa yang enak dan menyegarkan saat dikonsumsi sehingga dapat menutupi kelemahan dari rasa asli ekstrak tanaman yang digunakan [5].

Pada proses pembuatan sediaan tablet effervescent diperlukan tahapan awal yaitu membuat granul yang merupakan suatu produk antara sebelum masuk ke dalam tahapan pencetakan tablet. Granul tersebut dapat diperoleh dari proses granulasi, baik menggunakan metode granulasi basah, kering dan proses lain (humidification, priling, melt peletization) [6]. Proses granulasi ini bertujuan untuk membuat campuran serbuk menjadi granul yang memiliki ukuran yang lebih besar dengan bentuk yang lebih ideal yakni sferis. Granul yang diperoleh dari proses granulasi memiliki peran penting terhadap mutu fisik sediaan tablet yang dihasilkan. Sifat fisik granul yang dihasilkan dapat dipengaruhi oleh beberapa faktor seperti pemilihan eksipien, sifat fisik zat aktif serta metode granulasi yang digunakan [7].

Sediaan tablet effervescent membutuhkan beberapa komponen eksipien dalam formulasinya seperti pengisi, pemanis, komponen asam, basa, dan beberapa eksipien lainnya [4]. Bahan pengisi sekaligus pemanis yang digunakan dalam penelitian ini adalah kombinasi laktosa dan manitol. Pada formulasi sediaan effervescent kedua bahan ini sering digunakan karena memiliki rasa yang manis dan mudah larut di dalam air sehingga bila digunakan dalam formulasi tablet effervescent ekstrak daun senna diharapakan dapat menutupi rasa tidak enak dari daun senna dan juga dapat menghasilkan tablet effervescent yang memenuhi syarat kualitas tablet yang baik. Untuk mendapatkan produk akhir yaitu tablet effervescent yang memenuhi syarat kualitas, perlu dilakukan proses granulasi dan evaluasi granul terlebih dahulu agar tablet yang dihasilkan memenuhi syarat kualitas tablet yang baik. Penelitian ini bertujuan untuk mengetahui pengaruh kombinasi bahan pengisi laktosa dan manitol terhadap sifat fisik granul sebagai produk antara tablet effervescent ekstrak daun senna.

\section{Bahan dan Metode}

\section{Bahan}

Bahan yang digunakan pada penelitian ini memiliki kualitas farmasetis yaitu daun senna (diperoleh dari Sewon, Bantul, Yogyakarta), laktosa (Bratachem), manitol(Bratachem), asam sitrat (Bratachem), asam tartrat (Bratachem), natrium bikarbonat (Bratachem), PEG 4000 (Bratachem), dan akuades.

\section{Alat}

Moisture balance (Mettler HB 43), spray dryer (LabPlant), alat uji sudut diam dan waktu alir, alat uji pengetapan (Erweka), pengukur waktu alir, oven (Memmert), timbangan elektrik (Mettler Toledo ML303E), panci infusa, ayakan nomor 16 dan 60 , serta alat-alat gelas.

\section{Pembuatan ekstrak kering daun senna}

Ekstrak daun senna dibuat dengan menggunakan metode infundasi. Tiga ratus gram daun senna direndam menggunakan akuades dengan perbandingan 1:10 dan dipanaskan di atas penangas air selama 15 menit terhitung saat suhu telah mencapai $90^{\circ} \mathrm{C}$ sambil sesekali dilakukan pengadukan. Proses infundasi diulangi hingga empat kali. Infusa yang didapatkan digabungkan kemudian dikeringkan dengan pengeringan semprot (spray drying) dengan suhu inlet $120^{\circ} \mathrm{C}$, suhu outlet $63^{\circ} \mathrm{C}$, tekanan 1,5 bar, dan kecepatan alir $3 \mathrm{ml} / \mathrm{menit}$.

\section{Pembuatan granul ekstrak daun senna}

Ekstrak kering yang sudah didapat dicampur dengan laktosa hingga homogen. Asam sitrat, asam tartrat, natrium bikarbonat dan manitol yang sudah diayak dengan ayakan nomor 60 , dicampur ke dalam campuran ekstrak kering dan laktosa. Campuran tersebut lalu dimasukkan dalam oven pada suhu $\pm 50^{\circ} \mathrm{C}$ selama \pm 45 menit, setelah kering diayak dengan ayakan nomor 16 kemudian ditambahkan PEG 4000 dicampur hingga homogen, selanjutnya dilakukan evaluasi sifat fisik granul. Adapaun formulasi granul ekstrak daun senna dapat dilihat pada Tabel 1 .

Tabel 1. Formulasi granul ekstrak daun senna

\begin{tabular}{|c|c|c|c|}
\hline Bahan & $\begin{array}{c}\text { Formula I } \\
\text { (gram) }\end{array}$ & $\begin{array}{c}\text { Formula II } \\
\text { (gram) }\end{array}$ & $\begin{array}{c}\text { Formula III } \\
\text { (gram) }\end{array}$ \\
\hline $\begin{array}{l}\text { Ekstrak kering } \\
\text { daun senna }\end{array}$ & 33,00 & 33,00 & 33,00 \\
\hline Laktosa & 16,25 & 32,50 & 48,75 \\
\hline Asam sitrat & 15,62 & 15,62 & 15,62 \\
\hline Asam tartrat & 31,26 & 31,26 & 31,26 \\
\hline $\begin{array}{l}\text { Natrium bikar- } \\
\text { bonat }\end{array}$ & 53,12 & 53,12 & 53,12 \\
\hline PEG 4000 & 2,00 & 2,00 & 2,00 \\
\hline Manitol & 48,75 & 32,50 & 16,25 \\
\hline Total & 200 & 200 & 200 \\
\hline \multicolumn{4}{|c|}{$\begin{aligned} \text { Keterangan: } & \text { Formula 1: Laktosa: } \text { Manitol }=25 \%: 75 \% \\
& \text { Formula 2: Laktosa: Manitol }=50 \%: 50 \% \\
& \text { Formula 3: Laktosa: Manitol }=75 \%: 25 \%\end{aligned}$} \\
\hline
\end{tabular}

\section{Evaluasi karakteristik fisik granul}

Organoleptis; Diambil 1 gram granul, diletakkan di wadah yang bersih dan berlatar belakang putih. Diamati bentuk, warna, rasa, dan bau granul ekstrak daun senna menggunakan panca indra pada tempat yang terang. Hasil pengamatan yang diperoleh kemudian dicatat [8]

Waktu alir; Granul seberat 100 gram dimasukkan perlahan-lahan ke dalam alat uji waktu alir granul lewat tepi corong yang telah ditutup bagian bawahnya. Disiapkan stopwatch untuk mengukur waktu granul mengalir melewati corong, waktu pengukuran dimulai saat tutup corong dibuka. Tutup corong dibuka perlahan-lahan agar granul mengalir ke luar, stopwatch dimatikan saat seluruh granul telah ke luar. Dicatat berapa waktu yang tertera pada stopwatch [9].

Sudut diam; Granul ekstrak daun senna sebanyak 100 gram dimasukkan ke dalam alat uji sudut diam yang tertutup 
bagian bawahnya. Corong pada alat diatur dan diukur dengan ketinggian tertentu. Penutup kemudian dibuka dan biarkan seluruh granul mengalir ke bawah menuju alas horizontal sebagai dasar hingga membentuk tumpukan granul seperti kerucut. Nilai sudut diam dihitung menggunakan perhitungan Cotangen antara tinggi kerucut yang terbentuk pada alas horizontal [10].

Kompresibilitas; Dimasukkan granul ke dalam gelas ukur $100 \mathrm{ml}$, kemudian gelas ukur dipasang pada alat uji kompresibilitas dan diatur skala pengetapan sebanyak 100 kali per menit hingga didapatkan volume yang konstan. Persen kompresibilitas dan rasio Hausner dapat langsung dihitung pada saat uji pengetapan dengan cara menghitung bobot jenis sebelum dan sesudah pengetapan. Persen kompresibilitas dan rasio Hausner dihitung dengan menggunakan rumus [9].

$$
\begin{gathered}
\% \text { Kompresibilitas }=\frac{B J_{\text {mampat }}-B J_{\text {bulk }}}{B J_{\text {mampat }}} \times 100 \\
\text { Rasio Hausner }=\frac{B J_{\text {mampat }}}{B J_{\text {bulk }}}
\end{gathered}
$$

Susut Pengeringan; Sebanyak 1-2 gram granul ditimbang dalam wadah yang telah ditara, kemudian dimasukkan pada alat moisture balance dengan suhu $105^{\circ} \mathrm{C}$ selama $1-5$ menit.

\section{Analisis hasil}

Data yang diperoleh dianalisis dengan dua cara yakni menggunakan pendekatan teoritis dari literatur dan uji statistik menggunakan metode ANOVA dengan taraf kepercayaan 95\%. Uji yang dianalisis meliputi kecepatan waktu alir granul, sudut diam granul, pengetapan granul, dan uji susut pengeringan.

\section{Hasil Dan Pembahasan \\ Hasil uji organoleptis}

Evaluasi terhadap sifat fisik granul memiliki peranan yang sangat penting dalam proses pembuatan suatu tablet. Selain uji sifat fisik, uji organoleptis juga perlu dilakukan untuk mengetahui bentuk, warna, rasa, dan bau dari granul ekstrak kering daun senna yang dihasilkan. Uji organoleptis dilakukan dengan cara yang sederhana dan seobjektif mungkin dalam mendeskripsikan parameter organoleptis. Hasil uji organoleptis daun senna dapat dilihat pada Tabel 2.

Tabel 2. Data hasil uji organoleptis granul ekstrak daun senna

\begin{tabular}{cccc}
\hline Parameter & Formula I & Formula II & Formula III \\
\hline Bentuk & Granul & Granul & Granul \\
Warna & Kuning & Kuning & Kuning \\
Rasa & Manis & Manis & Manis \\
Bau & Khas ekstrak & Khas ekstrak & Khas ekstrak \\
\hline
\end{tabular}

Pada data hasil uji organoleptis ekstrak daun senna (tabel 2) menunjukkan bahwa tidak terdapat perbedaan pada bentuk, warna, rasa, dan bau granul ekstrak daun senna yang dihasilkan. Hal ini disebabkan jumlah ekstrak yang digunakan dalam formulasi tidak berbeda. Sehingga adanya variasi kadar pengisi laktosa dan manitol dalam formulasi tidak mempengaruhi parameter organoleptis granul yang dihasilkan. Bentuk dari granul yang dihasilkan memiliki karakteristik granul yang halus dan tidak berbentuk sferis, hal ini dapat dikarenakan jumlah cairan pengikat yang dihasilkan dari peleburan komponen asam dalam formula belum mencukupi untuk membasahi seluruh serbuk yang akan digranulasi.

Granul effervescent ekstrak daun senna yang dihasilkan memiliki bau khas ekstrak yaitu aroma khas dari daun senna. Sedangkan rasa yang dihasilkan dari granul ekstrak daun senna memiliki rasa yang manis karena penggunaan manitol dan laktosa dalam formulasi. Manitol dan laktosa merupakan eksipien yang sering digunakan dalam formulasi sediaan farmasi. Pada formulasi sediaan effervescent, manitol dan laktosa dapat digunakan sebagai pengisi sekaligus pemanis yang mudah larut dalam air [17]. Manitol dan laktosa memiliki karakteristik rasa yang manis dan enak dimulut sehingga dapat menutupi rasa tidak enak dari ekstrak daun senna yang digunakan.

Tabel 3. Data hasil uji sifat fisik granul ekstrak daun senna

\begin{tabular}{cccccc}
\hline For- & \multicolumn{5}{c}{$\mathbf{X} \pm$ SD* } \\
mula & $\begin{array}{c}\text { Waktu } \\
\text { alir } \\
(\text { detik) }\end{array}$ & $\begin{array}{c}\text { Sudut } \\
\text { diam } \\
\left({ }^{\circ}\right)\end{array}$ & $\begin{array}{c}\text { Carrs } \\
\text { Index }\end{array}$ & $\begin{array}{c}\text { Rasio } \\
\text { Hausner }\end{array}$ & $\begin{array}{c}\text { Susut } \\
\text { penge- } \\
\text { ringan } \\
(\%)\end{array}$ \\
\hline I & $4,53 \pm 0,13$ & $28,51 \pm 0,42$ & $27,67 \pm 1,15$ & $1,38 \pm 0,02$ & $1,07 \pm 0,12$ \\
\hline II & $4,49 \pm 0,16$ & $27,03 \pm 0,48$ & $28,00 \pm 1,00$ & $1,39 \pm 0,02$ & $0,33 \pm 0,12$ \\
\hline III & $4,34 \pm 0,05$ & $25,78 \pm 1,01$ & $28,00 \pm 0,00$ & $1,39 \pm 0,00$ & $0,27 \pm 0,12$ \\
\hline *SD : Standar deviasi (3 replikasi) & & \\
\hline \multicolumn{7}{c}{}
\end{tabular}

\section{Hasil uji waktu alir}

Pada tabel data hasil uji sifat fisik granul (tabel 3) menunjukkan bahwa formula I memiliki waktu alir yang paling lama dibanding formula II dan III. Perbedaan konsentrasi pengisi pada masing-masing formula tidak mempengaruhi waktu aliran granul karena pada penelitian ini granul yang dihasilkan memilki ukuran dan bentuk yang sama, sehingga waktu alir yang dihasilkan juga tidak berbeda walaupun ada variasi kadar laktosa dan manitol. Hasil data statistik dengan metode ANOVA antara variasi pengisi dengan waktu alir granul juga menunjukkan tidak ada perbedaan nilai yang signifikan $(0,208)$ antara formula I dengan formula II dan formula III atau dapat dikatakan ketiga formula memiliki nilai varian yang sama. Hasil ini menunjukkan bahwa variasi kadar laktosa dan manitol tidak mempengaruhi waktu alir granul effervescent ekstrak daun senna secara bermakna. Pada hasil uji waktu alir granul diketahui bahwa semua formula memenuhi persyaratan waktu alir, yaitu kurang dari 10 detik. Waktu alir yang kurang dari 10 detik menunjukkan bahwa granul mudah untuk mengalir sehingga waktu yang dibutuhkan granul untuk melewati corong alir semakin cepat. Granul dapat mudah mengalir atau tidak dapat dipengaruhi oleh beberapa hal, yakni ukuran granul, bentuk granul, sifat permukaan granul, densitas, dan kelembaban relatif $[14,15]$.

\section{Hasil uji sudut diam massa granul}

Pada tabel data hasil uji sifat fisik granul dapat dilihat bahwa semakin besar kadar manitol dan semakin kecil kadar laktosa maka sudut diam yang terbentuk akan semakin besar. Formula I dengan kadar manitol paling besar mempunyai sudut diam yang paling besar pula yaitu $28,51^{\circ}$. Sudut diam suatu granul dapat dipengaruhi oleh beberapa hal yakni bentuk, ukuran dan kelembaban granul. Granul yang lembab akan meningkatkan kohesivitas granulyang mengakibatkan menurunnya kualitas alir granul [13], sehingga menyebabkan waktu alir granul menjadi 
lebih lama dan sudut diam yang dihasilkan juga lebih besar. Hasil uji yang diperoleh menunjukkan bahwa, ketiga formula memiliki sudut diam yang dapat diterima, yakni $25-45^{\circ}$ [13]. Granul yang memiliki sudut diam $25-45^{\circ}$ akan mengalir dengan baik, semakin datar kerucut yang terbentuk artinya sudut kemiringan semakin kecil, maka sifat aliran granul semakin baik [13]. Data statistik dengan metode ANOVA menunjukkan adanya perbedaan nilai yang signifikan yaitu $(0,008)$. Hasil ini menunjukkan variasi kadar manitol dan laktosa akan mempengaruhi sudut diam granul ekstrak daun senna.

\section{Hasil uji pengetapan massa granul}

Pada tabel 3 dapat dilihat bahwa tidak ada perbedaan nilai carrs index pada masing-masing formula yang memiliki kadar pengisi yang berbeda. Hasil ini menunjukkan variasi kadar pengisi laktosa dan manitol yang berbeda-beda tidak mempengaruhi indeks pengetapannya. Perbedaan konsentrasi pengisi pada masing-masing formula tidak mempengaruhi indeks pengetapan massa granul, karena granul yang terbentuk dari masing-masing formula memiliki karakteristik yang hampir sama, yakni tidak memiliki bentuk yang sferis, kecil dan halus. Data statistik dengan metode ANOVA antara variasi pengisi dengan indeks pengetapan massa granul menunjukkan tidak ada perbedaan nilai yang signifikan $(0,216)$ antara formula I dengan formula II dan formula III atau dapat dikatakan ketiga formula memiliki nilai varian yang sama.

Pada hasil uji pengetapan massa granul diketahui bahwa semua formula memiliki sifat alir yang tidak bagus, karena memiliki nilai carrs index $>20$ dan rasio Hausner $>1,25$ [9]. Sifat alir yang bagus apabila memiliki nilai carrs index $<20$ dan rasio Hausner $<1,25$ [9]. Hasil uji sifat alir yang tidak bagus dikarenakan granul dibuat dengan metode peleburan, pada metode ini tidak ditambahkan cairan pengikat dari luar, melainkan cairan pengikat dihasilkan dari peleburan asam sitrat sehingga jumlah cairan pengikat yang didapat tidak banyak bila dibandingkan dengan penambahan cairan pengikat dari luar.

Cairan pengikat yang dihasilkan tidak mampu membasahi semua serbuk sehingga pada saat granulasi banyak serbuk yang tidak menjadi granul dengan sempurna dan menghasilkan granul dengan ukuran yang lebih kecil dan tidak memiliki bentuk granul yang bulat atau sferis sehingga mempengaruhi indeks pengetapannya. Granul dengan bentuk sferis biasanya akan lebih mudah menata diri sehingga dapat menurunkan indeks pengetapan, namun granul yang memiliki ukuran yang kecil dan tidak sferis akan lebih susah untuk menata diri saat dilakukan pengetapan karena ruang antar granul sudah terisi oleh udara sehingga indeks pengetapannya akan semakin besar $[14,15]$.

\section{Hasil uji susut pengeringan granul}

Pada tabel 3 dapat dilihat bahwa, formula I, II, dan III memiliki kadar air yang berbeda. Semakin besar kadar manitol dan semakin kecil kadar laktosa, maka granul akan menunjukkan kadar air yang semakin besar. Hasil ini menunjukkan bahwa variasi kadar manitol dan laktosa dapat mempengaruhi kadar air granul ekstrak daun senna, variasi ini disebabkan oleh sifat fisik dari manitol yang kurang stabil pada kondisi yang lembab, dan lebih stabil pada kondisi yang kering. Ketidakstabilan manitol ini disebabkan oleh kondisi ruangan yang digunakan saat pengujian granul yang menyebabkan asam sitrat yang bersifat higroskopis mengeluarkan air dan menyebabkan granul menjadi lembab. Keadaan lembab juga menyebabkan manitol yang tidak stabil menjadi basah dan kadar air granul semakin meningkat. Data statistik menggunakan metode ANOVA menunjukkan adanya perbedaan yang signifikan $(0,000)$ antara formula I, II, dan III. Berdasarkan hasil yang diperoleh, granul effervescent ekstrak daun senna memiliki kadar air yang diterima yaitu $<5 \%$ [13]

Kadar air yang semakin besar yang terdapat di dalam granul dapat mempengaruhi stabilitas dari tablet effervescent yang akan dibuat. Kadar air yang tinggi di dalam granul effervescent akan menyebabkan granul menjadi lengket pada punches dan susah saat dikempa [16]. Pada kondisi kadar air yang tinggi ikatan partikel akan lebih kuat karena luas kontak antar permukaan serbuk naik, apabila gaya tarik antar partikel serbuk semakin kuat, maka serbuk akan semakin sukar mengalir dan susah untuk dikempa, sebaliknya pada kadar air granul terlalu rendah akan menyebabkan tablet yang terbentuk menjadi lebih rapuh. Stabilitas tablet effervescent juga sangat rentan terhadap kondisi yang lembab, apabila granul memiliki kadar air yang tinggi maka dapat mengganggu stabilitasnya [16].

\section{Kesimpulan}

Penggunaan variasi kadar laktosa dan manitol sebagai pengisi dalam formulasi granul effervescent ekstrak daun senna berpengaruh terhadap sudut diam dan kadar air granul secara signifikan berdasarkan hasil analisis statistik. Sedangkan pada sifat alir dan waktu alir tidak menunjukkan adanya pengaruh dari variasi kadar laktosa dan manitol berdasarkan hasil analisis statistik yang tidak berbeda secara signifikan. Semakin besar konsentrasi manitol semakin besar kadar air dan sudut diam granul esktrak daun senna.

\section{Daftar Pustaka}

[1] Dewi, R. S., Fadilah, S., Illahi, N., Aryani, F., Pratiwi, E., dan Agustin, T.T. Persepsi Masyarakat Mengenai Obat Tradisional di Kelurahan Simpang Baru Kecamatan Tampan Kota Pekanbaru. J. Penelit. Farm. Indones. 2019; 8(2): 75-79.

[2] Sumayyah, S., dan Salsabila, N. Obat Tradisional : Antara Khasiat dan Efek Sampingnya. Majalah Farmasetika. 2017; 2(5).

[3] Jalwal, P., Middha, A., and Scholor, R. Recent advances on senna as a laxative: A comprehensive review Ramchander, Pawan Jalwal and Anil Middha. J. Pharmacogn. Phytochem. 2017; 6(2): 349-353.

[4] Mahdiyyah, M., Puspitasari, I. M., Putriana, N. A., dan Syamsunarno, M. R. A. Review: Formulasi dan Evaluasi Sediaan Oral Effervescent. Majalah Farmasetika. 2020; 5(4): 191-203.

[5] Wikantyasning, E. D., dan Nurwaini, S. Formulasi Tablet Effervescent Ekstrak Herba Sambiloto (Andrographis Paniculata (Burm F.) Ness.) dan Daun Dewandaru (Eugenia Uniflora Linn.). 2009; 10 (1):1-6.

[6] Elisabeth, V., YamLean, P. V. Y., dan H. S. Supriati, H. S. Formulasi Sediaan Granul Dengan Bahan Pengikat Pati Kulit Pisang Goroho (Musa acuminafe L.) dan Pengaruhnya Pada Sifar Fisik Granul. Pharmacon. 2018; 7(4): 1-11.

[7] Hadisoewignyo, L., dan Fudholi, A. 2013. Sediaan Solida, edisi 1. Yogyakarta : Pustaka Pelajar.

[8] Agoes, Goeswin. 2009. Teknologi Bahan Alam, edisi 2. 
Bandung : Penerbit ITB.

[9] USP. 2014. Method II-Measurement in a Volumeter. In : United States Pharmacopeial : the National Formulary. Rockville Md : The United States Pharmacopeial Conv. 2014-2016.

[10] Oetari, R., Sardjiman, Yuwono, T., dan A. Fudholi, A.Formulasi Senyawa Baru Antiinflamasi PGV-0 Dalam Bentuk Sediaan Tablet. Majalah Farmasi Indonesia. 2003; 14(3): 160-168.

[11] World Health Organization. 1999. WHO Monographs on selected medicinal plant, volume 1. Geneva : WHO Library, 241-242.

[12] Dave, H., and Ledwani, L. A Review on Anthraquinones Isolated from Cassia Species and Their Applicatations. Indian Journal of Natural Products and Resources. 2012; 3 (3) : 291-319.

[13] Parrott, E.L.. 1971. Pharmaceutical Technology Fundamental Pharmaceutics, 3rd Edition. Minneapolis : Burgess Publishing Company.

[14] Rani, K.C., Parfati, N., Muarofah, D., dan S. N. Sacharia, S. N. Formulasi Granul Effervescent Herba Meniran (Phyllanthus niruri L.) dengan Variasi Suspending Agent Xanthan Gum, CMC-Na, dan Kombinasi CMC-NaMikrokristalin Selulosa RC- 591. Jurnal Sains Farmasi dan Klinis. 2020; 7 (1) : 39-51.

[15] Kartikasari, S.D., Murti, Y.B dan Mada, U.G. Formulasi Tablet Effervescent Ekstrak Rimpang Jahe Emprit (Zingiber Officinale Rosc.) Dengan Variasi Kadar Asam Sitrat Dan Asam Tartrat. Tradisional Medicine Journal. 2015; 20 (2) : 124-132.

[16] Anwar, K. Formulasi Sediaan Tablet Effervescent Dari Ekstrak Kunyit (Curcuma domestica Val.) Dengan Variasi Jumlah Asam Sitrat-Asam Tartrat Sebagai Sumber Asam. Sains dan Terapan Kimia. 2010; 4 (2) : 168-178.

[17] Rowe, R.C. 2003. Handbook of Pharmaceutical Excipients, Fourth Edition. London : Pharmaceutical Press. 